\title{
Retraction Notice to: Brain Natriuretic Peptide Levels in Acute Inferior Myocardial Infarction
}

\author{
Editorial Office
}

It has been brought to our attention that the article "Brain Natriuretic Peptide Levels in Acute Inferior Myocardial Infarction", by Tarik Yildirim et al, published in Vol. 10, No. 3, 2018, p254-259, doi: http://www.doi.org/10.14740/jocmr3324w, is involved in redundant publication, this article was submitted to and published in Acta Medica Anatolia (Volume 5, Issue 1, 2017) before submitting to our journal. In line with COPE guidance, the editor of Journal of Clinical Medicine Research now retracts this article for the reason of redundant publication. 